\title{
Electronic Ticketing System and Traveler Purchasing Intention
}

\author{
HOÀNG TH!̣ PHƯỚng THẢO \\ Open University, HCMC \\ E-mail: thao.htp@ou.edu.vn
}

\section{ARTICLE INFO}

Received:

Dec. 21,2012

Received in revised form May 02, 2013 Accepted:

June 15, 2013

Keywords: e-ticketing purchasing intention Internet

\section{ABSTRACT}

This research aims to identify the importance of factors that influence customer intention of purchasing electronic air ticket (e-ticket). The research compares the difference in purchasing intentions based on eticketing between demographic groups of age, income, educational level, and online shopping experience. With the sample size of 295 travelers, the regression models and ANOVA tests are used to process and explain data. The research detects four components, namely, perceived system usefulness, perceived ease of use, perceived behavioral control, and security of transaction that influence the consumer intention to buy e-ticket. The paper then recommends managerial solutions to the development of an electronic ticketing system in particular and e-commerce in general. 


\section{INTRODUCTION}

Electronic ticketing system is still rather new in Vietnam. It can be seen as a prime example of e-commerce in Vietnam in the process of world trade integration. The goal is to offer customers more convenience when reserving and purchasing e-tickets via the Internet. Through this service, tickets can be ordered from anywhere and anytime over the website. Thus, all customers can use their personal computers, cell phones or other devices to order e-ticket. Flights are booked through the airline's website and customers are provided all the information relating to ticket booking services and the trading and settlement. Thus, the application of electronic booking model brings convenience and ease for customers, and helps the ticket vendors save cost and increase customer satisfaction (Lee, 2010).

Since 2007, Vietnam Airlines, the biggest airline corporation in Vietnam, has launched its e-ticketing service. Recently, many airlines participating in Vietnamese air transport market such as Tiger Airways, Air Asia, Jetstar Pacific, Air Mekong, etc. have made the e-ticketing system more popular. This type of service quickly meets the needs of Vietnamese customers, which implies that the application of the service model is feasible and effective and tends to grow in Vietnam market.

However, trading in an online market differs from trading in a traditional one. Most Vietnamese consumers still choose the traditional method to buy air ticket rather than electronic method because they perceive risks in online transaction. In order to attract customers toward the online channel, e-ticket airlines should understand Vietnamese customer attitudes toward online purchasing to build an effective e-ticketing program in the Vietnamese context. This research aims to answer two questions: "What are the factors influencing customer intention on purchasing electronic air ticket?" and "What are the differences among various demographic groups of customers in purchasing intention for electronic air ticket?"

\section{LITERATURE REVIEW AND HYPOTHESIS DEVELOPMENT}

E-ticketing is a form of e-commerce whereby customers reserve a seat in an airline's database system, and payment is made through the Internet (Hoosain et al., 2000). An eticking system enables travelers that book an airline ticket to get a copy of their receipt containing the record locator or reservation number and the e-ticket number instead of the old-style paper ticket. E-ticketing is a technological innovation. Whether or not 
travelers will adopt e-ticketing, therefore, depends to a certain extent on their assessment of the technology.

\section{a. Online Purchasing Intention:}

Intention is the instruction that people give themselves to behave in certain way. Specifically, purchasing intention shows the likelihood that a customer actually wants to buy (Chen et al., 2002). Intention is frequently used as an important determinant of online purchasing behavior. It is customer intention to exchange information online, share confidential information and take the transaction online (Pavlou, 2003). Intention is defined as the strength of conscious plan to perform the targeted behavior (Keil et al., 1995). "Intention to use" rather than "actual behavior" is chosen as the dependent variable for both theoretical and practical reasons. Theoretically, acceptance of eticketing is an individual's psychological state with regard to his or her voluntary intention to use a particular system (Gattiker, 1990). Using behavioral intention as a dependent variable to study individual acceptance of a new technology, therefore, is theoretically valid. This research is conducted in the early stages of e-ticketing development in Vietnam when it has not been widely adopted by travelers. Therefore, it is practical to use intention as a proxy for actual usage. In the emergence of diverse air ticket retail outlets and increasing competition in the market, online retailers must understand factors affecting online purchase intention that lead to the increase in online sales. Some previous research mentioned perceived usefulness (Davis, 1989; Jaruwachirathanakul \& Fink, 2005), perceived ease of use (Davis, 1989; Zeithaml et al., 2002), perceived behavioral control (Ajzen, 1991; Pavlou, 2003), security of online transaction (Udo, 2001; Chueng \& Lee, 2005) and subjective norms (Fishbein \& Ajzen, 1975) as antecedents of customer purchasing intention online.

\section{b. Perceived Usefulness:}

This factor shows that the level of people's belief in a particular system would enhance his or her job performance (Davis, 1989). Chen et al. (2002) suggested that perceived usefulness is an important factor in determining adaptation of innovations. In the situation of online customer behavior, previous researchers discovered that perceived usefulness affects customer attitude toward online shopping (Jaruwachirathanakul \& Fink, 2005). It may state that the greater the perceived usefulness of e-ticketing services, the more likely e-ticket will be adopted. Hence, the following hypothesis is proposed: 
H1. There is a positive relationship between perceived usefulness and traveler purchasing intention toward electronic air ticket.

\section{c. Perceived Ease of Use:}

This factor refers the level of people's belief that using a particular system would be free of effort (Davis, 1989). Zeithaml et al. (2002) stated that the degree to which an innovation is easy to understand or use could be considered as perceived ease of use. In this study, perceived ease of use refers to the degree to which travelers believe that using the e-ticketing system for purchasing e-tickets via the Internet would be easy to do. The ease of use of the company's e-commerce systems can determine how well companies can attract and retain customers. In other words, perceived ease of use explains a large portion of the variance for intention to use information technology (Gefen et al., 2003). So it is proposed that:

$H 2$. There is a positive relationship between perceived ease of use and traveler purchasing intention toward electronic air ticket.

\section{d. Perceived Behavioral Control:}

This factor presents one's perception about the ease or difficulty in performing the behavior (Azjen, 1991; Athiyaman, 2002). This is important in explaining human behavior since an individual who has intentions of accomplishing certain action may be unable to do so because his or her environment prevents the act from being performed (Pavlou, 2003). For online purchasing intention, computer use, internet access, and availability of online assistance are all behavioral control factors, which are important in process of shopping online. Azjen (1991) noted that perceived behavioral control over engaging in the behavior is a factor influencing intention. So it is suggested that:

H3. There is a positive relationship between perceived behavioral control and traveler purchasing intention toward electronic air ticket.

\section{e. Security of Online Transaction:}

This is a key evaluative criterion in online services to build trust in a long-term relationship (Chueng \& Lee, 2005). There are two related criteria that have been distinguished from each other. Security involves practices of protecting users from the risk of fraud and financial loss from the use of their credit card or other financial information - not sharing personal information about customers with other sites, protecting anonymity, and providing informed consent. Security concern is one of the 
main reasons Internet users give for not purchasing over the Internet (Udo, 2001). In this study, security refers to the level at which travelers believe in the safety of e-ticketing system so that they decide to buy e-ticket via the Internet. Hence, we propose:

$H 4$. There is a positive relationship between security of online transaction and traveler purchasing intention toward electronic air ticket.

\section{f. Subjective Norms:}

They refer to one's perception of social pressure to perform or not to perform the behavior under consideration. Hartwick \& Barki (1994) suggested that the subjective norm is more significant in the initial step of implementing an information system. This element refers to the influence of other individuals to a person's attitude. They can be very important people who have strong influence on society. Their approvals or disapprovals of certain behavior can affect other people and create the motivation to comply or follow their actions or behaviors. Prior studies have suggested that subjective norm tends to be important during the introductory stages of adoption when people who intend to use a new technology have limited direct experience with it (Gefen et al., 2003). In Vietnam, e-commerce is in the early stage of development. Traveler's friends, family, and colleagues who have experience in shopping online may affect them in purchasing e-tickets. Thus, it is proposed:

$H 5$. There is a positive relationship between subjective norms and traveler purchasing intention toward electronic air ticket.

\section{RESEARCH METHODOLOGY}

The research is carried out with two main steps: preliminary research and formal research. The preliminary research is performed by in-depth interviews. Ten Vietnamese travelers frequently traveling by plane are invited to engage in face-to-face interviews. Half of them have already bought e-tickets. All of them use Internet on a daily basis and intend to buy e-tickets in the future. This approach is to identify factors that affect customer intention pattern. It helps adjust observed variables and measurement scale to a particular situation of electronic air ticket service, as well as related terms. The interviewers use semi-structure questionnaire which lists main questions to ask during the interview and which can be changed to make it appropriate to each respondent. Specifically, 25 draft statements of six constructs developed from the literature review are presented to respondents for their assessment. The result of preliminary research shows that almost factors/variables are rather sufficient, clear and understandable to 
travelers. Two unclear items of perceived usefulness are removed, and one new item of perceived ease of use is added to gain the sufficient research factors to suit e-ticketing situation in Vietnam. This result directs the design of quantitative questionnaire for the next step of research process. The completed scale is built in Table 1.

The quantitative questionnaire is designed with 24 items measured by a Likert scale. There are six main constructs: perceived usefulness ( 3 items), perceived ease of use (5 items), perceived behavioral control (5 items), security of transaction (4 items), subjective norms (4 items), and buying intention (3 items).

Table 1: Measurement Scale of the Main Constructs

Item code Observed variables

\section{Perceived usefulness}

PU 1 Using e-ticketing helps me reduce the risks of lost or left-out tickets.

PU 2 The e-ticketing procedure helps me buy air tickets conveniently.

PU 3 The e-ticketing system helps me save time.

\section{Perceived ease of use}

PE 1 The credit card paying practice is easy to perform in e-ticket website.

PE 2 The e-ticket website loading speed is high.

PE 3 The e-ticket website is always accessible 24/7.

PE 4 Clear and detailed information about price, quantity and different kinds of e-tickets is available.

PE 5 Clear and detailed information about the code, time and place of flight is available.

\section{Perceived behavioral control}

PB1 My monthly income affords the e-ticket.

PB2 I use personal computer (or laptop) at home or office to search for an e-ticket on the Internet.

PB3 I have credit cards to pay for an e-ticket via the Internet.

PB4 I have sufficient skills to use computer and Internet to make online purchasing.

PB5 I have general knowledge and experience about buying online.

\section{Security of online transaction}


SP1 Paying procedure for an e-ticket is highly safety.

SP2 All private information of travelers is kept secret by e-ticket website administrators.

SP3 Website provides telephone number and email address of airlines for travelers to connect when necessary.

SP4 Website has compensation policy for travelers when paying mistake occurs.

\section{Subjective norms}

SN1 My colleagues/friends provide related information and motivate me to buy e-tickets.

SN2 My family provides related information and motivates me to buy e-tickets.

SN3 Information of celebrities from traditional channel (TV, newspapers) supports my buying e-tickets.

SN4 Information of celebrities from a modern channel (SMS, social network, e-magazine) supports my purchase of an e-ticket.

\section{Purchasing intention}

PI 1 I intend to buy e-tickets in the near future.

PI 2 I determine to buy e-tickets in the near future.

PI 3 Although I can buy paper tickets at airlines agents, I still choose buying e-tickets in the near future.

The expected sample consists of 340 Vietnamese passengers who often travel by airplane. The respondents were chosen by convenience sampling method. Respondents were screened by a question of intention of buying electronic air ticket. The selfadministered questionnaires were distributed to travelers at Tân Sơn Nhất airport while they were waiting for check-in. The response rate was $89 \%$, and eight poor answer sheets were eliminated. Finally, there were 295 answer sheets satisfying the requested information for analysis purpose. Data were coded and processed with tests of factor analysis, correlation, multiple regression analysis and one-way ANOVA. Table 2 shows the profile of respondents. The sample includes $51 \%$ male and $49 \%$ female. Their ages vary from 25 to $34(44 \%)$ and from 35 to 49 (28\%). These age groups are very sensitive to information technology environment, search for and review of online products. More than $40 \%$ of respondents have an average monthly income from VND10 to 14.9 million. They tend to choose electronic air ticket because they own personal computer and credit card. Regarding respondents' education level, the college/university group accounts for 
$66 \%$. The officer group accounts for the largest share of sample (56\%), followed by the group of managers (23\%). The respondents work in a dynamic environment, get access to new environments quickly and often seek information via the Internet. More than onethird of the sample uses the Internet in 10-20 hours per week, and one-fourth of them access it around 5-10 hours per week.

Table 2: Profile of the Sample

\begin{tabular}{|c|c|c|c|}
\hline & \multirow{2}{*}{ Characteristics } & \multicolumn{2}{|c|}{$n=295$} \\
\hline & & Frequency & Percentage (\%) \\
\hline \multirow{2}{*}{ Gender } & Male & 150 & 50.8 \\
\hline & Female & 145 & 49.2 \\
\hline \multirow{4}{*}{ Age } & Less than 25 & 54 & 18.3 \\
\hline & $25-34$ & 130 & 44.1 \\
\hline & $35-49$ & 84 & 28.4 \\
\hline & $>50$ & 27 & 9.2 \\
\hline \multirow{4}{*}{ Education } & Under high school & 6 & 1.7 \\
\hline & High school & 29 & 9.7 \\
\hline & College/university & 195 & 66.1 \\
\hline & Above university & 65 & 22.5 \\
\hline \multirow{4}{*}{ Occupation } & Officer & 165 & 55.7 \\
\hline & Worker & 29 & 9.7 \\
\hline & $\mathrm{CEO} /$ manager & 66 & 22.5 \\
\hline & Student & 35 & 12.1 \\
\hline \multirow{6}{*}{$\begin{array}{l}\text { Personal } \\
\text { income }\end{array}$} & $<$ VND 5,000,000 & 38 & 12.8 \\
\hline & VND 5,000,000- 9,900,000 & 71 & 24.2 \\
\hline & VND $10,000,000-14,900,000$ & 127 & 43 \\
\hline & > VND15,000,000 & 59 & 20 \\
\hline & $<5$ hours & 57 & 19.4 \\
\hline & $5-10$ hours & 73 & 24.8 \\
\hline
\end{tabular}


Weekly $\quad 10-20$ hours

Internet

access time
106

59
35.8

20

\section{RESEARCH RESULT}

\section{a. Factor Analysis:}

An exploratory factor analysis is to validate the measurement model. To evaluate the concept of the scale, the reliability test is applied with the coefficient of Cronbach's alpha of higher than 0.7 (Churchill, 1979). The reliability test result shows that all Cronbach's alpha coefficients of the constructs range from 0.745 to 0.911 . As such, 24 observed variables are reliable and will be used for further analysis. To guarantee convergent validity, items with factor loadings, which are not significant or below 0.5 , are eliminated (Bagozzi, 1994). At the first rotated round of the independent variables, five components are extracted and one item is deleted (PB5: I have knowledge and experience to buy online) because of low factor loading $(0.345<0.5)$. Table 3 presents the second rotated round result of exploratory factor analysis based on 23 variables. The five factors of independent variables are extracted at least Eigen value of 1.065, all factor loadings are higher than 0.5 , ranging from 0.620 to 0.913 . The highest cumulative coefficient is $73.5 \%$.

Table 3: Factor Analysis and Reliability

\begin{tabular}{|c|c|c|c|c|c|c|}
\hline \multirow{2}{*}{ Construct } & \multirow{2}{*}{ Code } & \multicolumn{5}{|c|}{ Factor loading } \\
\hline & & 1 & 2 & 3 & 4 & 5 \\
\hline Perceived usefulness (PU) & PU1 & 0.661 & & & & \\
\hline Cronbach's $\alpha=0.749$ & PU2 & 0.785 & & & & \\
\hline Eigen value $=4.756$ & PU3 & 0.701 & & & & \\
\hline Cumulative $\%=73.530$ & & & & & & \\
\hline Mean $=4.15$ & & & & & & \\
\hline Perceived ease of use (PE) & PE1 & & 0.687 & & & \\
\hline Cronbach's $\alpha=0.911$ & PE2 & & 0.743 & & & \\
\hline Eigen value $=1.065$ & PE3 & & 0.765 & & & \\
\hline Cumulative $\%=37.065$ & PE4 & & 0.756 & & & \\
\hline
\end{tabular}




\begin{tabular}{|c|c|c|c|c|c|}
\hline Mean $=3.95$ & PE5 & & & & \\
\hline Perceived behavioral control (PB) & PB 1 & & 0.866 & & \\
\hline Cronbach's $\alpha=0.745$ & PB2 & & 0.796 & & \\
\hline Eigen value $=5.796$ & PB3 & & 0.694 & & \\
\hline $\begin{array}{l}\text { Cumulative } \%=69.018 \\
\text { Mean }=3.04\end{array}$ & PB4 & & 0.620 & & \\
\hline Security of online transaction (ST) & ST1 & & & 0.690 & \\
\hline Cronbach's $\alpha=0.854$ & ST2 & & & 0.903 & \\
\hline Eigen value $=2.345$ & ST3 & & & 0.826 & \\
\hline $\begin{array}{l}\text { Cumulative } \%=63.222 \\
\text { Mean }=3.74\end{array}$ & ST4 & & & 0.742 & \\
\hline Subjective norms (SN) & SN1 & & & & 0.865 \\
\hline Cronbach's $\alpha=0.813$ & SN2 & & & & 0.860 \\
\hline Eigen value $=3.409$ & SN3 & & & & 0.910 \\
\hline $\begin{array}{l}\text { Cumulative } \%=52.561 \\
\text { Mean }=2.52\end{array}$ & SN4 & & & & 0.913 \\
\hline Purchasing intention (PI) & PI1 & 0.940 & & & \\
\hline Cronbach's $\alpha=0.908$ & PI2 & 0.911 & & & \\
\hline $\begin{array}{l}\text { Eigen value }=2.544 ; \mathrm{KMO}=0.743 \\
\text { Cumulative } \%=84.805\end{array}$ & PI3 & 0.911 & & & \\
\hline Mean $=4.38$ & & & & & \\
\hline
\end{tabular}

Purchasing intention is uni-dimensional with three observed items. With Varimax rotation of principal component method, only one component is extracted and gets Eigen values of 2.544. The KMO coefficient is 0.743 and Barlett's test of sphericity has high significance $(\mathrm{Sig} .=0.000)$. All three factor loadings are higher than 0.9 , and Cronbach's alpha is 0.908 . The means of all research constructs range from 2.52 to 4.38 , in which mean of traveler purchasing intention is rather high (4.38) and mean of subjective norms is lower than average (2.52).

\section{b. Correlation Analysis:}


Correlation coefficients are used to quantify the level of close relationship between two or more variables. Absolute value of correlation coefficient closes to 1 when the variables have a tight linear correlation. If the correlation is lower than 0.85 , discriminant validity exist between two variables (John \& Benet-Martinez, 2000). Table 4 summarizes the correlation matrix of six constructs which were analyzed by Pearson with 2-tailed assumption. Correlation of each pair of constructs is from -0.029 to 0.548 (lower than the conditional index of 0.85 ) which proves that the main constructs gain discriminant validity. Thus, the measurement scale meets requirement of measuring different constructs.

Table 4: Correlation Matrix

\begin{tabular}{lcccccc}
\hline \multicolumn{1}{c}{ Constructs } & PE & SN & ST & PB & PU & PI \\
\hline Perceived ease of use (PE) & 1.000 & -0.029 & $0.306^{* *}$ & $0.415^{* *}$ & 0.158 & $0.513^{* *}$ \\
Subjective norms (SN) & & 1.000 & 0.031 & 0.039 & -0.151 & 0.060 \\
$\begin{array}{l}\text { Security of online transaction } \\
\text { (ST) }\end{array}$ & & 1.000 & 0.142 & $0.254^{* *}$ & $0.261^{* *}$ \\
$\begin{array}{l}\text { Perceived behavioral control } \\
\text { (PB) }\end{array}$ & & & & & \\
$\begin{array}{l}\text { Perceived usefulness (PU) } \\
\text { Purchasing intention (PI) }\end{array}$ & & & & & & \\
\hline
\end{tabular}

Note: $* *$ Pearson correlation is significant at $\mathrm{p}<0.01$ level (2-tailed).

\section{c. Multiple Regression Analysis:}

After confirming the acceptability of the measurement model, the estimation of the regression model is performed. The estimated results are shown in Table 5. This table details the results of multiple regression model to test the relationship between the major factors of e-ticketing system (perceived ease of use, subjective norms, security of online transaction, perceived behavioral control, and perceived usefulness) and customer purchasing intention. VIF indexes vary from 1.031 to 1.325 (less than 10) and Tolerance indicators are higher than 0.1 , which indicate very low multicollinearity among the variables. 
The adjusted $\mathrm{R}^{2}$ of regression model of 0.540 implies that $54 \%$ of variance of dependent variable is generally explained by five independent variables in the model. The F-value with significance at $\mathrm{p}<0.001$ indicates that the outcome model is very suitable for the collected data, and there is a good fit between the dependent variable and predictors $(\mathrm{F}$ value $=37.212 ; \mathrm{F}$ sig. $=0.000)$. There are four independent variables affecting the dependent variable at a statistically significant level $(\mathrm{p}<0.05)$. They are ranked as following orders: perceived usefulness $\left(\beta_{1}=0.460\right)$, perceived ease of use $\left(\beta_{2}=\right.$ $0.343)$, perceived behavioral control $\left(\beta_{3}=0.215\right)$ and security of transaction $\left(\beta_{4}=0.129\right)$. The element of subjective norms $\left(\beta_{5}=0.085\right)$ is eliminated from the model because its significance level is higher than 0.05 .

Table 5: Regression Analysis

\begin{tabular}{llccccc}
\hline $\begin{array}{c}\text { Dependent } \\
\text { variable }\end{array}$ & Independent variables & $\begin{array}{c}\text { Beta } \\
\text { coefficient }\end{array}$ & $\begin{array}{c}\mathbf{t} \\
\text { value }\end{array}$ & Sig. & Tolerance & VIF \\
\hline $\begin{array}{l}\text { Purchasing } \\
\text { intention }\end{array}$ & Perceived usefulness & 0.460 & 7.976 & 0.000 & 0.899 & 1.112 \\
& Perceived ease of use & 0.343 & 5.449 & 0.000 & 0.755 & 1.325 \\
& $\begin{array}{l}\text { Perceived behavioral } \\
\text { control }\end{array}$ & 0.215 & 3.650 & 0.018 & 0.857 & 1.167 \\
& Security of transaction & 0.129 & 2.322 & 0.021 & 0.970 & 1.031 \\
& Subjective norms & 0.085 & 1.410 & 0.161 & 0.820 & 1.219 \\
\hline & Adjusted $\mathrm{R}^{2}=0.540$ & F value $=37.212$ & F sig. $=0.000$ & \\
\hline
\end{tabular}

The results of relationships between the independent variables and the dependent variable in the regression model lead to the conclusion that most hypotheses $(\mathrm{H} 1, \mathrm{H} 2$, $\mathrm{H} 3$, and H4) cannot be rejected, except for H5. If travelers highly perceive system usefulness, ease of use, security of transaction, and behavioral control of using website, they will intend to buy e-ticket. In other words, the higher the level of perceived usefulness and ease of use, the greater the intention to buy e-ticket; the higher the degree of behavioral control and security of online transaction, the greater the e-ticket purchasing intention. In addition, travelers can decide to buy e-ticket themselves and do not rely on other person opinions (subjective norms).

\section{d. One-way ANOVA Analysis:}


One-way ANOVA test is used to compare the different mean scores of e-ticket purchasing intention among groups of demographic variables.

Table 6: One-way ANOVA Result

\begin{tabular}{|c|c|c|c|c|c|c|c|}
\hline \multirow[b]{2}{*}{$\begin{array}{c}\text { Group } \\
\text { difference }\end{array}$} & \multirow[b]{2}{*}{$\mathbf{n}$} & \multirow[b]{2}{*}{ Mean } & \multirow[b]{2}{*}{$\begin{array}{l}\text { Std. } \\
\text { dev. }\end{array}$} & \multicolumn{4}{|c|}{ Post Hoc tests } \\
\hline & & & & Group A & Group B & $\begin{array}{c}\text { Mean } \\
\text { difference } \\
\text { (A-B) }\end{array}$ & Sig. \\
\hline \multicolumn{8}{|l|}{ Age } \\
\hline Less than 25 & 54 & 3.69 & 1.049 & Less than 25 & Age of 25-34 & $-0.892 *$ & 0.001 \\
\hline From 25 to 34 & 130 & 4.58 & 0.653 & Less than 25 & Age of 35-49 & $-0.747 *$ & 0.009 \\
\hline From 35 to 49 & 84 & 4.44 & 0.861 & & & & \\
\hline More than 50 & 27 & 4.01 & 0.763 & & & & \\
\hline \multicolumn{8}{|l|}{ Income } \\
\hline $\begin{array}{l}\text { Less than VND5 } \\
\text { mil. }\end{array}$ & 21 & 3.84 & 1.062 & $\begin{array}{l}\text { Less than } \\
\text { VND5 }\end{array}$ & $\begin{array}{l}\text { More than } \\
\text { VND15 }\end{array}$ & $-0.779^{*}$ & 0.041 \\
\hline $\begin{array}{l}\text { From VND5 to } \\
9.9 \text { mil. }\end{array}$ & 40 & 4.35 & 0.893 & million & million & & \\
\hline $\begin{array}{l}\text { From VND10 to } \\
14.9 \text { mil. }\end{array}$ & 71 & 4.47 & 0.694 & & & & \\
\hline $\begin{array}{l}\text { More than } \\
\text { VND15 mil. }\end{array}$ & 33 & 4.64 & 0.822 & & & & \\
\hline \multicolumn{8}{|l|}{ Education } \\
\hline $\begin{array}{l}\text { High school and } \\
\text { under }\end{array}$ & 35 & 3.85 & 1.062 & $\begin{array}{l}\text { High school } \\
\text { and under }\end{array}$ & $\begin{array}{c}\text { Above } \\
\text { university }\end{array}$ & $-0.801 *$ & 0.026 \\
\hline $\begin{array}{l}\text { College/ } \\
\text { university }\end{array}$ & 195 & 4.44 & 0.774 & & & & \\
\hline $\begin{array}{l}\text { Above } \\
\text { university }\end{array}$ & 65 & 4.57 & 0.826 & & & & \\
\hline
\end{tabular}

Occupation 


\begin{tabular}{|c|c|c|c|c|c|c|c|}
\hline $\begin{array}{l}\text { Student and } \\
\text { worker }\end{array}$ & 64 & 3.86 & 1.046 & $\begin{array}{l}\text { Student \& } \\
\text { worker }\end{array}$ & Officer & $-0.682 *$ & 0.002 \\
\hline Officer & 165 & 4.54 & 0.669 & Student \& & $\mathrm{CEO} /$ manager & $-0.706^{*}$ & 0.007 \\
\hline $\mathrm{CEO} /$ Manager & 66 & 4.56 & 0.834 & worker & & & \\
\hline \multicolumn{8}{|c|}{ Internet access time } \\
\hline $\begin{array}{l}\text { Less than } 5 \\
\text { hours/week }\end{array}$ & 57 & 3.84 & 1.050 & $\begin{array}{l}\text { Less than } 5 \\
\text { hours }\end{array}$ & $5-10$ hours & $-0.766^{*}$ & 0.004 \\
\hline $\begin{array}{l}\text { From } 5 \text { to } 10 \\
\text { hours/week }\end{array}$ & 73 & 4.61 & 0.666 & $\begin{array}{l}\text { Less than } 5 \\
\text { hours }\end{array}$ & 10-20 hours & $-0.580 *$ & 0.045 \\
\hline $\begin{array}{l}\text { From } 10 \text { to } 20 \\
\text { hours/week }\end{array}$ & 106 & 4.42 & 0.724 & $\begin{array}{l}\text { Less than } 5 \\
\text { hours }\end{array}$ & $\begin{array}{c}\text { More than } 20 \\
\text { hours }\end{array}$ & $-0.792 *$ & 0.008 \\
\hline $\begin{array}{l}\text { More than } 20 \\
\text { hours/week }\end{array}$ & 59 & 4.64 & 0.822 & & & & \\
\hline
\end{tabular}

Note: $(*)$ Significance at $\mathrm{p}<0.05$.

Table 6 shows that key customers of e-ticket are travelers in the age from 25 to 49 , and their mean scores are considerably higher than those of the group of customers less than 25 and more than 50 years of age. People with income "less than VND5 million" $($ mean $=3.84)$ have less purchasing intention than people with income "more than VND15 million" (mean =4.64). Hence, travelers having higher incomes tend to buy eticket more than lower income travelers.

The high education group is directed toward purchasing e-ticket more than low education groups (mean of 4.57 compared with mean of 3.78). Both groups of managers ( mean $=4.57)$ and officers (mean $=4.54$ ) have stronger intention to buy e-ticket than groups of students and workers (mean $=3.86$ ). The high education group with their occupation as managers or officers has better knowledge of IT and regularly uses computers, so they prefer to buy ticket online. Travelers who access Internet less than 5 hours per week have the lowest intention to buy e-ticket.

\section{CONCLUSION AND MANAGERIAL IMPLICATIONS}

The paper indicates that four out of five proposed factors affect e-ticket purchasing intention. The most important factor is perceived usefulness, followed by perceived ease of use, perceived behavioral control and security transaction. Perceived usefulness has 
much more of an effect on the decision to shop than ease of use does since the website must fulfill a consumer's shopping needs. The e-ticketing system is in the process of early deployment in Vietnam and brings many benefits to buyers which help change consumer buying behavior from traditional channel into modern one. Consumers are delighted with usefulness and easiness of online process of providing the air service. With the weak IT infrastructure in a developing country like Vietnam, consumers are hesitant to use credit card payment system. Obviously, security of online transaction is an important factor to impact on buying e-ticket.

The finding demonstrates the differences in e-ticket purchasing intention among groups of travelers. Despite much worrying of security, travelers are very fond of buying ticket via the Internet (mean $=4.4$ in the scale from 1 to 5 ). Traveler groups of age between 25-49, who are CEO/managers or officers, are actually high potential customers of e-ticketing service. Their higher income and educational level lead them to stronger intention of buying e-ticket. The more travelers use the Internet the more they intend to buy e-ticket. The overall experience of using the website and finding the service the traveler desires can have a significant impact on both the initial shopping experience as well as the traveler's intention to return to that site. The traveler must believe that he/she is in control. If the traveler does not have an enjoyable shopping experience or does not feel in control throughout the buying process, then the traveler will abandon the site and find another source for the service. Thus, airlines should try to construct a reliable system, and overcome psychological barriers to stimulate these travelers to use the eticketing system frequently.

In order to increase passengers' perception of usefulness of e-ticketing system, airlines need to advertise widely on mass commercial media to help travelers know eticketing system and educate them in advantages of e-ticket compared with paper ticket. Airlines can improve their selling policy to make travelers become aware of usefulness of the online ticketing. For example, airlines can allow travelers to purchase more than 9 tickets per time rather than constraint of this severe amount. Some airlines such as Vietnam Airlines and Jetstar Pacific Airlines still have not supported travelers in changing the flights immediately. Travelers must contact a physical airline agent, cancel old ticket, book a new one and pay a changing fee. These airlines should add this extra function to their websites to save time and cost for travelers. 
Most travelers are aware of the ease of e-ticketing system. Actually, design of eticketing websites is rather simple. They only provide clear information, and consistent detailed indication for travelers to buy online ticket at the first time. However, travelers have to click many times and go through many pages to book online tickets successfully. This suggests that airlines should design their web pages in such a way to minimize the amount of time necessary for customers to acclimatize to the site. The web pages of booking ticket should be accessible with minimum numbers of clicks. Having an eticketing website for customers is not enough. It is necessary to produce updated service information through the website and to maintain a user-friendly site. Moreover, airlines should invest more bandwidth to avoid congestion when a large number of travelers access the website at the peak times such as Tết or summer holidays.

The perceived behavioral control covers some monetary variables as respondent's income, technological facilities (network computer, laptop, and smart phone), means of paying (Visa, Master card) and Internet usage skills. Airlines should diversify the forms of payment instead of accepting credit cards only. To attract more potential customers, airlines' promotion campaign should focus on higher income and educational groups with age segment from 25 to 49 . Officers and CEO/managers are subjects to receive airlines ads through the Internet.

Customer's trust in airlines website is based partly on the security of transaction. In order to create traveler trust, airlines should strengthen their website security system to prevent hackers from stealing money from credit cards of travelers. Airlines also can devise e-ticketing procedures which travelers consider more trustworthy than current practice.

\section{LIMITATION AND FURTHER RESEARCH}

The paper presents the factors affecting customer purchasing intention toward eticketing based on the customer perception. However, customer perception changes overtime, and Internet is growing day by day. So a longitudinal study is necessary to repeatedly observe the same variables over long periods of time to find the true online shopping phenomena. In addition, the paper has just focused on the intention of travelers toward buying e-ticket rather than assessing the actual buying behavior. Other researches can be done to measure both purchasing intention and actual purchasing behavior in a specific service. 
Additionally, the sample of 295 travelers in HCMC with the convenient sampling is not enough to represent the overall e-ticket purchasing intention of entire Vietnam population. Hence, future researches with larger samples in representative cities of Vietnam could be done to achieve the generalization

\section{References}

Athiyaman, A. (2002), "Internet Users Intention to Purchase Air Travel Online: An Empirical Investigation", Marketing Intelligence \& Planning, 8(3): 234-242.

Azjen, I. (1991), “The Theory of Planned Behavior", Organizational Behavior and Human Decision Processes, Vol. 50, pp. 179-211.

Bagozzi, R.P. (1994), "Measuring in Marketing Research: Basic Principles of Questionnaire Design", Principles of Marketing Research, Cambridge MA: Basil Blacwell, 1-49.

Chen, L.D., M. L. Gillenson \& D. L. Sherrell (2002), “Online Consumers: An Extended Technology Acceptance Perspective", Information and Management, pp.705-719.

Cheung, C.M.K. \& M.K.O. Lee (2005), “An Integrative Model of Consumer Trust in Internet Shopping”, European Conference on Information System (ECIS, 2003), Naples, Italy.

Churchill, J. (1979), “A Paradigm for Developing Better Measures of Marketing Constructs”, Journal of Marketing Research, 26(1), 64-73.

Davis, F. (1989), "Perceived Usefulness, Perceived Ease of Use, and User Acceptance of Information Technology”, MIS Quarterly, 7(8): 319-339.

Gattiker, U.E. (1990), Technology Management in Organizations, Sage, Newbury Park, CA.

Gefen, D., E. Karahanna \& D.W. Straub (2003), “Trust and TAM in Online Shopping: An Integrated Model”, MIS Quarterly, 27(1): 51-90.

Hartwick, J. \& H. Barki (1994), "User Participation, Conflict, and Conflict Resolution: The Mediation Roles of Influence”, Information Systems Research, 5(4): 422-438.

Hoosain, A., S. Khan, D. Kira \& A. Farhoomand (2000), “Japan Airlines: Impact of e-ticketing”, In

K.C. Laudon \& J.P. Laudon (Eds.) Management Information Systems: Managing the Digital Firm (8th Ed.) pp. 511-520, Englewood Cliffs, NJ: Prentice Hall.

Jaruwachirathanakul, B. \& D. Fink (2005), "Internet Banking Adoption Strategies for a Developing Country: The Case of Thailand", Internet Research, 15(3): 295-311.

John, O.P. \& V. Benet-Martinez (2000), "Measurement: Reliability, Construct Validation, and Scale Construction", In H.T. Reis \& C. M. Judd (Eds.), Handbook of Research Methods in Social Psychology, pp. 39-369, New York: Cambridge University Press.

Keil, M., P.M. Beranek \& B.R. Konsynski (1995), "Usefulness and Ease of Use: Field Study Evidence Regarding Task Considerations", Decision Support Systems 13(1): 75-91. 
Lee, C. (2010), "Including Subjective Norm and Technology Trust in the Technology Acceptance Model: A Case of e-ticketing in China", The DATA BASE for Advances in Information Systems, 41(4): 40-51.

Pavlou, P. (2003), "Consumer Acceptance of Electronic Commerce: Integrating Trust and Risk with the TAM", International Journal of Electronic Commerce, 7(3), 101-134.

Udo, G.J. (2001), "Privacy and Security Concerns as Major Barriers for E-Commerce: A Survey Study", Information Management and Computer Security, MCB University Press, pp. 165-174.

Zeithaml, V.A., A. Parasuraman \& A. Malhotra (2002), "Service Quality Delivery Through Websites: A Critical Review of Extent Knowledge", Journal of the Academy of Marketing Science, 30(4): 362-375. 